\title{
National Literature, Collective Identity and Political Power
}

Published in Comparative Social Research (2003), Volume 21, 111-145

Fredrik Engelstad, University of Oslo/Institute for Social Research

fredrik.engelstad@sosgeo.uio.no

Department of Sociology and Human Geography University of Oslo

P.O.Box 1096 Blindern

N-0317 OSLO Norway

Telephone: $\quad+4722855257$

Fax: $\quad+4722855253$

Internet: http://www.iss.uio.no 


\title{
NATIONAL LITERATURE, COLLECTIVE IDENTITY AND POLITICAL POWER
}

\author{
Fredrik Engelstad
}

\begin{abstract}
The significance of literature in nation-building in two "second generation" nations, Germany and Norway, is discussed. In both countries a specific national literature was constituted parallel to the political institutions during the latter half of the 19th century. Yet there are clear differences in political effects in the two cases. In Norway, the struggle for national independence up to 1905 entailed a significant democratization of society. Germany, in the wake of the revolution of 1848 , developed into a politically authoritarian regime, fully established under Prussian leadership in 1871.

These processes are mirrored in the position of literature. In Norway, where artistic traditions were absent, the national literature was a product of the 19 th century, and emerged in close connection to ongoing political debates. In Germany, the Weimar heritage had gained classical status during the 1850 s. Thus, the problem was foremost that of redefining the spiritual heritage to fit the history of the German Reich.

A related difference is found in the diffusion of literature through its most important channel - the school system. Norway developed a modern, uniform school, where the nation's new literature was accorded a central place. In Germany, a more class-based school system was cemented, and the idea of diffusing the cultural heritage to the population at large held a weak position.

Along with these institutional factors, the development of national literatures in the two countries is seen in the light of regional specificities,
\end{abstract}

Comparative Studies of Culture and Power

Comparative Social Research, Volume 21, 111-145

(C) 2003 Published by Elsevier Ltd.

ISSN: 0195-6310/doi:10.1016/S0195-6310(03)21005-X 
constellations of literary genres with high and low prestige, and the social and political position of writers.

\section{INTRODUCTION}

Discussions of the ambiguous relationships between literature and social and political power have a long history. Literature has been conceived as a reflection of dominant power relations, either directly - as bearing the stamp of society's hegemonic forces, or indirectly - as an unintended criticism of the same power relations. Or, literature was seen as a progressive force by virtue of its contribution to enlightenment in a more general sense, as a criticism of inconsistencies in the dominant culture, a depiction of ethical dilemmas, or as a source of critical reflection on language and narration. Alternatively, literature has been put to use as an instrument of adaption to existing society or as a vehicle for social change, by aligning itself with collective movements, most prominently as a call for proletarian literature, but for a long time as a strand of feminist and regionalist writing as well. Albeit in a less instrumental way, literature was accorded a central role in nation-building processes during the 19th century. In the age of globalization this does not seem obvious any more, but it is of essential for understanding the foundation of the literary institutions in the industrialized world.

The development of national literatures in Europe after the Renaissance was connected to the fate of nations, and the formation of national power apparatus. The parallel rise of the novel and of the nation in Europe from the late 18th century (Thiesse, 1999) may serve as a metaphorical expression, even if literature certainly comprises much more than the novel. Classical cases are England and France. English literature achieved close relations to the power apparatus already in the Elizabethan epoch, with the crown and nobility acting as patrons of poets and a large number of theatre troupes (Ingram, 1992). Somewhat later, the French Academy was established by the absolutist regime in late 17th century in order to regulate and cultivate French language and literature. In the spirit of centralization the court administered the yardstick by any artistic achievement could be measured (Blanning, 2002). Due to geopolitical factors, wars and conquests, French and English national identities emerged relatively early and developed over several centuries. Their national identity was already well established when the second wave of nation-state formation was sweeping over Europe during the 19 th century. Compared to the first wave, the second wave of nation-building had two distinct features: the ideas of nationality were already developed, making the emergence of national identities a much more dense process. Moreover, it occurred 
simultaneously with the industrial revolution in large parts of Europe. Thus, in this phase the nation-state evolved as a response to two objectives: creating an institutional and legal framework for an industrial economy, and setting up institutions of socialization for the population as a whole.

The present article focuses on this second wave. Among the second wave countries, two are singled out for comparative analysis, Germany and Norway, with primary emphasis on literary life in the second half of the 19th century. The two countries are well suited for comparison as they are sufficiently similar and different on core variables. In both countries, literature played a prominent role in the formation of socio-political culture. Both sprang into existence as modern nation-states in the years after 1850 . Institutional impulses and cultural influence - in literature and the arts, architecture, and legal system - traveled in both directions, albeit most forcefully from Germany to Norway. At the same time, the political situation in the two countries was strikingly dissimilar. Germany was emerging as a major actor on the European scene, whereas Norway was a small country struggling for national liberation and democratization. The literary situation also was different. In Germany, the summit of literary achievement was already reached early in the 19th century, a central task thus being that of canonization and reformulation of the heritage for modern society. In Norway, with hardly any trace of modern literary production before 1830 , the task was that of building a separate national literature almost from the ground.

The exposition proceeds as follows. First, I present a general argument for the significance of literature in nation-building. Then I discuss the specific political problematiques and literary institutions in Germany and Norway, as well as the constitution of the reading public. Then the next section takes up a social movement perspective, outlining the role of literature in regional movements and national politics in the two countries. The concluding section, draws some general lines, ends with a few general reflections on literature and nationality.

\section{POWER AND CULTURE IN NATION-BUILDING}

"Power" is a many-faceted concept. Here it is taken in its elementary meaning, the ability to influence action. The power of literature is of course symbolic in its nature, based on its ability to influence readers' perceptions, beliefs and values (Engelstad, 2001). It has a role in nation-building to the degree that it contributes to the shaping of the world-view of citizens and thereby fosters legitimacy and loyalty to the nation-state. Literature as a link between the individual and the nation is mediated by social institutions. In order to understand the complex interplay with power, literary works must be seen in connection with literature as a social 
institution, the expansion of the readership, the formation of literary markets and the constitution of literary canons. Generally, literary institutions are national in their nature, to the extent that they embrace a common language and a common set of socio-political problematiques (Griswold, 1987).

The main focus in the present context is that of power on the national level, as the capacity of a political apparatus to act on behalf of a nation. These actions may be directed both internally, e.g. in erecting viable welfare services, or externally in trade relations and foreign policy. Legitimacy is central for the exercise of power in any political apparatus, but is most precarious in modern societies. Modernization increases enormously the personal autonomy of citizens, but this elicits a comparable increase in the need for social coordination and discipline. This contradictory process makes legitimacy a central concern in modern nation states. Salient sources of legitimacy of the nation are instrumental factors such as the system for political governance, the military apparatus, and the economic infrastructure, but in addition cultural and symbolic formations play a decisive role (Mann, 1986).

In order to operate as political entities, modern nations must rely on collective identities, i.e. feelings of belonging, support, and identification with the nation state among their citizens. A modern state cannot do without a public sphere where citizens can discuss common problems, how to shape social institutions and maintain social order (Blanning, 2002; Habermas, 1989), as well as common conceptions of their mission vis-à-vis other states. This implies that citizens should develop identities that enable them to act autonomously in society and to see their own interests and conceptions of self as linked to those of their fellow citizens. Thereby, the nation's cultural and artistic achievements, among which literature in many cases is the most widespread, have a separate and crucial effect in the nation-building process.

\section{The Neglect of Literature}

Despite a widespread agreement among social scientists that culture holds a salient place in nation-building, surprisingly little attention has been given to the role of literature. In a now classic statement on nationality, Benedict Anderson (1983) pointed out that nations must be conceived as "imagined communities." From the 16th century, the expansion of markets, communications and new technology transcended the borders of traditional small-scale communities, and formed the basis for larger units of belonging. In this process, Anderson puts special emphasis on the modes of communication - the standardization of national languages and the development of the printing industry. However, Anderson aligns with a basically 
causal approach. Communication technologies are analyzed as preconditions for the formation of national identities, vehicles for an extended exchange of goods and ideas. With a few exceptions added in the second edition of Imagined Communities (1991), the specific forms that the expression of national identity may take is not explored.

By contrast, in The Invention of Tradition (1983), Eric Hobsbawm and Terence Ranger take a strictly intentional approach. They highlight the erection of lieux de mémoire as a part of modern nation-building: public monuments, official ceremonies, flags, national anthems, as support for national ideology. The realist bend of their title notwithstanding. Hobsbawm and Ranger do not treat these forms as epiphenomena, but regard cultural expressions as necessary parts of modern societies. However, a deeper understanding of why this is so is absent from their exposition, except the observation that if a national symbolism does not exist it has to be invented. And again, literature is largely overlooked.

The same is true for more recent contributions. Liah Greenfeld traces different versions of early European nationalism in her Nationalism. Five Roads to Modernity (1992). Likewise, Anthony Smith explores the cultural dimensions of nationalism and national identity (Smith, 1991), not least by taking further the analysis of cultural rituals and artifacts in Myths and Memories of the Nation (1999). Even if the names of a few writers are briefly mentioned, however, the literary world is strikingly absent in the work of these authors. Similarly, Michael Hechter's Containing Nationalism (2000), which also underlines the salience of national identity, hardly makes reference to literature.

The absence of artistic achievements in general and literature more specifically, is felt as well in empirical research on nation-building in Germany and Norway. In his historical-sociological descriptions of Norway, Stein Rokkan (1970) focused on the mobilization of the periphery, on organizational initiatives, political institutions, and counter cultures. But he did not discuss the significance of the main culture and of national literature. Of course, Rokkan's broad historical analysis of cleavages in Europe includes religious alignments and schisms, but here too, the arts are absent. Likewise, in his monumental reinterpretation of Norwegian history Rune Slagstad (1998), while setting the concept of identity formation at the core of the exposition, devotes only a few pages to the Norwegian "poetocracy." The dominant national character in the latter half of the 19th century, the writerpolitician Bjørnstjerne Bjørnson, is not included among his national strategists. In contrast, in explorations by Bernhard Giesen and co-workers (1991) of national and cultural identity, literature is accorded a visible part in studies on Germany, however, the connections to national building processes remain quite vague.

Yet, two studies are the exception that proves the rule. The work by Peter Uwe Hohendahl on the development of literary history in 19th century Germany, 
Building a National Literature (1989) situates changes in the writing of literary history within the political processes in Germany 1830-1870. Hohendahl takes the literary institution as his primary focus. Nationalism and Literature by Sarah M. Corse (1997) is a thorough study of literature and nation-building in the U.S. and Canada with emphasis on the second half of the 20th century. Given the geographical focus, and her concentration on the narratives at the cost of literary institutions, the work of Corse is more peripheral to the present study. Nevertheless, some of her main theses will be taken up in the concluding section.

The main reason for this neglect of literature in the nation-building studies can hardly be that literature is regarded by social scientists as less important than other cultural expressions. I rather assume the contrary. Probably, the problem is rather that literature is firmly established as a separate scholarly field. Hence, studies of the social effects of literature is mostly left to scholars in that field. These academics, on the other hand, albeit well aware of the national dimensions in literary history, seldom cross the boundary to the neighboring fields in the social sciences.

\section{Literature and National Legitimacy}

A point of departure may be taken in Max Weber's conception of legitimacy. In his view, the power of the traditional ruling class is justified by myths of origin, mostly with a religious flavor (Weber, 1922). The development into modernity entails a significant change in the modes of legitimizing state power: they lose their personal character, and legitimacy is transferred to social institutions. Not a prince or a king, but political constitutions and assemblies, educational institutions and cultural heritage, are focal points of legitimacy on the national level. At the same time, myths of origin still make up a salient part of national mythology.

The work of Pierre Bourdieu on literature (1993, 1996) directly addresses institutional themes, and develops further some parts of Weber's thinking on power and legitimacy. Bourdieu's conception of field and struggles for hegemony, and his empirical analyses of French literary life, point to the core of the present discussion. His distinction between various segments in the literary field (avant-garde, mainstream, and popular literature), and the roles of mediators and judges of taste connected to them, are very useful. Bourdieu's conception of the relationship between micro and macro structures, however, are less fruitful to the analysis of nation-building. He links the micro and macro level by "habitus," an abstract and ahistorical concept. Despite the weight accorded to struggles for hegemony, his macro descriptions tend to be exceedingly static. 
Bourdieu's main focus is on power from above. Processes of nation-building, however, must also be viewed from below. They presuppose mobilization of broad strata of the population, by participation in social movements, formulation of normative claims, and development of collective identities. Literature gains power by being widely diffused, appealing to large groups of people. These elements are absent from Bourdieu's theorizing. Hence, the analysis of literary institutions has to be complemented by theory developed mainly within social movement studies.

The most relevant theory on social movements in this respect is that of Alberto Melucci (1989), which has collective identity as its central axis. "Collective identity" in Melucci's terms does not refer to some supraindividual entity, but describes a set of preconditions for concerted action: In order to act efficiently, participants must have common conceptions that embrace the cognitive, relational and emotional level. The cognitive component refers to means-ends relationships, the actions and plans to be executed. The relational aspect concerns who are relevant partners in interaction, whereas the emotional relates to the attachment felt by participants toward the movement and its goals (Melucci, 1989, pp. 70-81).

These points apply to social movements in general. More specifically, literature and other narratives form an important part of many, maybe most, social movements. Cognitively, through the moral problems depicted in the plot. Relationally, the link is connected to belonging, to roots, foremost to a given territory, but also to more permanent ethnic or ideological groups may serve as a link between personal identities and the abstract linguistic community. Emotionally, the link may be characterized as compassion in the Aristotelian sense, leading up to recognition and attachment to cultural patterns or ways of life.

When the nation is the frame of reference, the focus is set on literary institutions and institutionalized literary activity. Here, we are able to make a similar distinction. On the cognitive level, we can place the various activities comprising what may be called "literary selection": criticism, canonization, censorship, and selection for educative purposes. The relational concerns the literary expression as signal of community and common linguistic heritage. In macro, the emotional level concerns what may be termed literary culture, i.e. the generalized preferences for literary works, exchange and discussion of literary quality and appeal.

Social movements often accord a special status to writers. Writers affiliated to the cause may be used to express and explain the goals of the movement. Some not only embody the voice of the movement, but due to their expressive capacity form a part of its actual leadership. The mobilizing effects of literature increases to the degree that the moral conflicts depicted in literature bear the stamp of literary quality - the great writer embodies the movement also by bestowing its themes with aesthetic authority. 


\section{Why Literature?}

A salient question remains, however: Why put weight on literature? There are alternative narrative and expressive forms that convey national legitimacy, of which history is probably the most salient. In line with Weber's conception of legitimacy, history may be seen as the justification of the present population in defiance against intruders and occupants. Thereby, power holders, and the structure of power distribution, are legitimized as well. The past points up to and explains the present. In this sense, writing the history of a group implies legitimizing a set of claims on its behalf. History is also a source of identity as it expresses what "we" are. We, who share a common fate here and now, do so in virtue of being an extension of "us" in the past.

If history creates commonality in time, common fate in space is expressed through the mass media. The mass media are the core of the public space, as Anderson (1983) makes clear when he underlines the salience of language and printing. But the media do something more, by making the demarcation of the public sphere visible, and thereby demonstrating who are expected to take part in it, and who not. Coordination of interpretation and expectations presupposes perceptible boundaries between own group and external domains. These are expressed in delimitations of arenas of public exchange (Lamont \& Fournier, 1992).

Boundaries change continuously. Political and intellectual leadership consists to a great extent in the ability to persuade others to change their frames of references in this sense, and to build up institutional structures to make this possible: make people see themselves as proletarians and not only as workers in a given factory, or as Germans and not only as Prussians or Bavarians. Thus, national identities are built and shaped (Smith, 1991; Thiesse, 1999), not least through strategies of distinction of own nation from others (Corse, 1997). In that way a separate place is opened for the arts, and not least literature, in nation-building.

With reference to the 19th century, in a condensed formula, literature stands in a unique position to legitimize the nation as a people. Art, and foremost literature due to its reproducibility, is the privileged medium for envisaging the life and fate of the people. In the 19th century literature was the dominant medium of mass expression, the only art form able to reach a large mass of consumers. Except for reading ability, literature does not presuppose any specific skills or instruments. The narrative component enables it to recreate and dramatize long-term social processes, and thereby interpret the common fate of a whole people. This refers not to single pieces of literature, but to the totality, the country's literary tradition. It not only serves as demarcation, by drawing a boundary between the in-group and the out-group, but it also contributes to a positive definition of the in-group, demonstrating who "we" are along several dimensions: 
- The quality of the arts of a nation is a measure of its creative potential, as compared to other nations.

- Literature bears witness of "our" past by reinterpreting and recreating historical events, folktales, myths and mores, and calling the past into life in a way inaccessible to specific historical narratives.

- Literature demonstrates the breadth of the nation by depicting "our" diverse landscapes, and thus enhancing solidarity across local communities.

- The national spirit is actualized by elaboration through literature of "our" understanding of life problems, longings, spiritual struggles and norm conflicts.

- Literature is the main, albeit not the only, source of creativity of the national or standardized language. In the long run, a language that is not constantly renewed in its expressive qualities will stagnate and slowly die.

Literature can only achieve these social effects, however, on the condition that it is experienced as more than these effects, i.e. that it exercises fascination and has a value quite independent of its desirable qualities as a medium of social integration. Because it appeals to other layers of the personality, literature can reinforce sentiments and experiences related to the nation, thereby enhancing the national consensus and its political potential.

\section{The Construction of a National Literature}

The establishment of a national literary institution presupposes the cooperation of several groups of actors. Wendy Griswold (2001) has made a useful distinction between a "reading class" and a "reading culture." The reading class is composed of those actors that have reading and writing as their central occupational task, such as journalists and teachers. A reading culture is achieved when a substantial part of the population has reading as one of their preferred activities, thereby bringing a robust literary market into existence. A reading class may exist without a reading culture, as is the case in many Third World countries today (Griswold, 2000). However, long term development of a national literature presupposes the existence of a reading culture. If it does not yet exist, the reading class may take on the task to construct it.

A reading class, however, does not operate as an integrated group, but must be broken down to a fairly large set of roles. At least three sets of actors are essential in the development of a national literature: (i) producers: writers, publishers and printers; (ii) interpreters: intellectuals, critics, teachers; and (iii) public officials: politicians and civil servants stimulating or regulating the literary activity, by influencing market processes, instituting education, and funding libraries. 
That a national literature is dependent on writers, is a truism. If writers are to make a living they are dependent on getting their books distributed to a public. Thus, a national literature presupposes a critical mass of professional publishers. Publishers constitute a literary milieu for writers, in addition to their command over technical and financial resources and their practical relationship to printers, bookstores, and advertising media.

Moreover, for a literature to be construed as "national," it must be the object of synthesizing work by critics. Due to its links to the newspapers and journals, criticism defines a relevant realm for literature, within the greater public sphere. Mediating between writers and the public, critics cannot control the production of literary works, but they may be able to give voice to the development of new literary schools, interpret literary history and point to directions in which writers ought to move. This process may be the result of contact between critics and writers, or by writers also functioning as critics (Bourdieu, 1993, 1996).

Within Academia, criticism works post hoc, reinterpreting and adapting interpretations within a given national direction. Literary history grew out of the simultaneous development of individualism and nationalism, merged into a narrative compound of collective creativity (Kittang, Meldahl \& Skei, 1983). Academic criticism stays aloof from the creative process, and may in principle stand at a distance from the general public as well. In the academic setting, criticism takes the form of literary history, something that gives the scholar a privileged position in deciding on the national canon. Canonization may be seen as a continuous writing and rewriting of history. Hence, the process of interpretation and canonization is enhanced by literary history developing into a separate academic discipline. In general, universities form an important part of national cultures (Hobsbawm, 1962). To an even greater extent this is true of the university positions of literary history. When they emerged around 1860 both in Germany and Norway, ${ }^{1}$ national literature was legitimized by the advanced historical-scientific methods of the day.

Albeit further removed from the creative processes, politicians and bureaucrats are responsible for the nation's cultural policy in a broad sense, and regulate public access to literature. Probably the most important effects of the political system on the reading culture are mediated by the educational system. Schools transmit reading abilities to the next generation, but in a wider sense also knowledge about literature, abilities of interpretation, and more general potentials of appropriation of literature. The general school system, in turn, is dependent on institutions of higher learning, which are the most important centers for synthesizing and transmission of literary history.

Censorship and the demarcation of freedom of expression, is another crucial part of cultural policy. Censorship may be handled directly by the legal system, or by 
more indirect means. Moreover, public officials play an important role for the diffusion of books, by their commercial regulation of the book trade in general and of the distribution of books through libraries. The political system may also regulate the access to literature by direct or indirect patronage. Scholarships for authors, public support for publishing and for theatres are the most prominent elements in this category (Griswold \& Engelstad, 1998). Patronage is by no means restricted to the state. In Germany in particular, local princes and private donators played an important role in funding and building a national theatre as well as acting as patrons to writers.

\section{LITERATURE AND POLITICS IN GERMANY AND NORWAY}

When Germany and Norway were confronted with the task of building a nationstate during the second half of the 19th century, both were defining the nation on the basis of long-term historical precedents, as well as the upheavals resulting from the Napoleonic wars.

For centuries, Germany was an assembly of principalities and smaller kingdoms, partly in loose coalitions, partly members of large empires, but none of them as a national state in the modern sense. The German defeat in the first half of the Napoleonic wars brought the old German-Roman empire to an end, and provoked a specific German nationalism linked to the romantic movement (Greenfeld, 1992). But national sentiment lacked an appropriate political edifice as its counterpart. After the wars the principalities were politically allied in a rather loose German Federation which, however, was plagued by constant rivalries for leadership between Austria and Prussia. From the middle of the 19th century, the principalities in the German area came under growing pressure for political and economic liberalization. An industrialized economy was emerging. Germany could not possibly foster a viable modern economy and maintain its political status in Europe without a larger state formation. But which "Germany"?

In this situation, the failed revolution of 1848 had two significant effects. On the one hand, it contributed to strengthening reactionary trends in the ruling classes, in the German states as in the rest of Europe. On the other hand, this became decisive for the rise of Prussia as the center for German nationalism. The necessity of forming a modern nation-state in order to meet the challenges of modernization entailed a debate between two main alternatives: a "Great German" state including all or most of the German-speaking area, most probably under the leadership of Austria, or alternatively a kleindeutsch - "Little German" - solution comprising German states outside the Habsburg empire. Prussia brought the debate to an 
end during the 1860s by three successful wars led by Prussia: against Denmark in 1864, against Austria in 1866, and against France in 1870. Thereby a new German empire was established as a kleindeutsch national state under Prussian dominance.

Like Germany, Norway found itself in a new situation after the Napoleonic wars. For three hundred years a colony under Denmark, the country was forced into a political union with Sweden as a part of the Kiel treaty of 1814. The union, however, was quite loose, leaving Norway a separate constitution and parliament and a high degree of home rule. Nevertheless, national self-assertiveness was growing throughout the century, and most markedly from the 1840 s. In combination with political reforms during the latter half of the century, this ultimately led to the dissolution of the union with Sweden in 1905.

Being latecomers in the industrial revolution and the process of economic modernization, both Germany and Norway were to a large degree state-led economies in the 19th century. Albeit governed by liberal ideology, the "Norwegian system" of economic development (Seip, 1957) consisted in an active state building out financial institutions and large-scale transportation systems. This seemingly contradictory system was a response to the low level of resources in a small and poor country. In Germany, economic modernization likewise took place under the leadership of a strong state bureaucracy. However, this was not caused by the resource situation of the country, but by the heavy traditions of state regulation in Prussia from early 18 th century. Even if visibly present in the economy in both countries, the strong state was characterized by a different ideological orientation and a different rationale: in Norway, the state supporting initiative from below, in Germany regulation from above.

Similar differences are found in the patterns of social and political conflict. Rapid industrialization in the latter half of the 19th century in Germany led to the emergence of a broad working class and a very active labor movement. The German social democratic party was leading in Europe after its foundation in 1875. However, it soon faced drastic resistance to regular democratic procedure. The so-called Socialist laws, effective 1878-1890 prohibited any organizational activity in the party, even if the party itself was not banned (Willms, 1983). In Norway mass industrialization did not occur before the turn of the century. The Labor party did not get its first representatives in Parliament before 1903. The latter half of the 19th century was the period of political inclusion of small farmers, not so much the coming to terms with the labor movement. Political tensions created by the emergence of the working class were weaker than in Germany, but at the same time more open.

State-led modernization entailed comprehensive school reforms in the latter half of the 19th century. In secondary schools the concentration on classical 
languages, history and philosophy was gradually complemented and replaced by education mainly based on the sciences and modern languages. This took place in both countries, in Norway to a considerable extent inspired by Germany. In both countries school reforms were strongly influenced by national considerations. Nevertheless, underlying ideologies were dissimilar. Norwegian, school reforms from the mid-century had a definitive democratic flavor, the overarching goal being a cultivation of the general population, as expressed in the idea of the unitary school towards the end of the century. The break with classical education was legitimized both by national and democratic concerns. In Germany, in contrast, national ideals were linked to the idea of Bildung, to a large extent based in the school reforms around 1800, inspired by Humboldt and Fichte, where classical languages were dominating. Even if the general level of education was raised considerably during the 19th century, the school system in Germany remained heavily class-bound, in accordance with Prussian political and social structure (Müller, 1989).

\section{Germany - Definition and Redefinition of the National Heritage}

When the strivings for the constitution of a modern national state in Germany took hold at the middle of the 19th century, a prolific German literature was already in existence. At the death of Goethe in 1832, the greatest achievements in German cultural history, the works of Lessing, Schiller and Goethe, along with the philosophical works of Kant, Hegel and Schelling, were already a part of history. After the failure of the 1848 revolution, literary debate in Germany primarily centered on canonization of past works rather than on the liberal and progressive promises of a new literature. A focal point in the canonization process was the celebration of Schiller's centenary in 1859 (Hohendahl, 1989). Thereby, Goethe and Schiller's Weimar was instituted as the central metaphor of the summit of national literature and the hallmark of German spirituality.

The "Germanness" of this German culture had some peculiar traits compared to the already established nation-states in Europe. The conception of "nation" in Germany up to the middle of the 19th century was linked to a well-established common German language and culture, not to the state. Thus, the hallmark of self-understanding in German culture was that of universalism: a universal philosophy, that of the German idealist tradition, and a universal humanism balancing classicism and romanticism. This universality was based, among other things, on the fact that no centralized German nation state was in existence, in contrast to the great European powers France and Great Britain. Goethe was a convinced cosmopolitan, not a nationalist in any sense. Typically, as a means to create 
German national unity, Schiller recommended establishing a national theatre, not a nation-state.

The Napoleonic wars were to be a turning point for German nationalism. In his Discourses to the German Nation (1808), Fichte outlined his conception of German nationality as supra-historical, the true metaphysical national spirit being primordial to historical development (Greenfeld, 1992). This conception of the nation was followed up during the first decades of the 19th century. The romantic movement sought the true spirit of the people in its myths and fables, most famously collected by the Grimm brothers. In a parallel movement, the spirit of the people was sought in its literature. Already by 1830,16 voluminous literary histories were published (Batts, 1993). Public debate on the fate of the nation was to a large extent directed to the development of literature, literary criticism and its aesthetic problems (Hohendahl, 1989).

In the years leading up to the constitution of the kleindeutsch solution to the problem of a German nation-state, traditional German universalism came increasingly under strain, something that made the task of historical redefinition necessary (Hobsbawm \& Ranger, 1983). The problem is demonstrated in a telling detail. Up to the middle of the 19th century most of the large body of German literary histories contained the notion of "nation" in their title, such as History of the German National Literature. ${ }^{2}$ After 1860 this use of the concept of nation almost disappeared (Batts, 1993), due to its connotation to the Great German idea. How could the culture of a broad nation without a state be accommodated to the creation of a new nation-state? To patriotic literary theorists and literary historians the kleindeutsch solution posed two problems. First, the notion of "German literature" had to be redefined from a universal literature to a more narrow national literature - the literature of the German Reich. Second, and no less demanding, given the weight accorded to historical evolution, a long term continuity, an "inner" line of development where the Prussian heritage had played a crucial role, had to be demonstrated (Hohendahl. 1989; Hüppauf, 1972). However, this posed a serious challenge as the military-bureaucratic state of Prussia had played a relatively marginal role in the development of the German literary heritage, despite the intellectual flourishing of Berlin from about 1815 .

As a long term result, the tensions between spiritual traditions and political development created a deep split in German culture. Traditional national universalism was confronted by an assertive political nationalism based on the "blood and iron" of military conquest, the Reich being founded on three wars in less than ten years. Simultaneously, there was little understanding within circles of literary theory and academic interpretation for the actual creative achievements of the day. Admittedly, the realist literature from the 1850 s onwards could not 
compete with the achievements of Weimar. But the works by authors as Gottfried Keller, Adalbert Stifter, C. F. Mayer and Theodor Storm were undervalued in contemporary criticism and literary history (Bentin et al., 1993), and marginalized as "village" literature. In the general public they were overshadowed by now mostly forgotten nationalist writers such as Gustav Freytag, whose novel Soll und Haben (1855) was the most read novel of the 19th century (Sagarra, 1971).

In Hohendahl's view, inspired by the work of Habermas (1989) on the public sphere, a major effect of this tension was a split between literary history and the public cultural discourse: debates on literature and literary history were pushed out of the public sphere, seeking refuge in the universities as a philological specialty rather than manifesting themselves in the public realm in reflections on the national fate. The public sphere was the victim of commercialization of the modern mass media. As a reaction, conservative historicism took the lead in literary interpretation, as is illustrated by the intellectual development of Wilhelm Dilthey, the most prolific scholar in the humanities of his time (Hohendahl, 1982, 1989).

Maybe this is expecting too much from literature. How could a country leaping into modernity, developing a large industrial sector in a few decades, constituting a national state, have its literary history as a dominant concern in its public debates? Literary criticism did not disappear from the public realm or from the press, even if it had to adjust to the journalistic requirements of the modern press (Berman, 1988). Moreover, the establishment of literary history as a separate academic discipline around 1860 was a logical consequence of the growth of the cultural and historical disciplines within universities, and not so much a result of political changes.

Nevertheless, the German cultural scene to an increasing degree was marked by cultural struggles between modernizing tendencies and the humanities increasingly taking a conservative and nationalist stand.

\section{Norway - Constructing a National Literature}

In contrast to Germany, hardly any specificly Norwegian literature was in existence in 1832, the year of Goethe's death. The challenge to the new nation was not so much to reinterpret the literature of the recent past within a national paradigm as to construct a wholly new literature. At that time, literary life in the young nation did not comprise a sufficient critical mass, neither a self-sustaining reading class nor a reading culture. Classicist heritage was weak, cultural life amateurish, and dependent on Danish impulses and translations. Building a new, national language 
distinct from Danish, which had been dominant for centuries, was seen as an urgent task. Paradoxically, while Germany had a language without a state, Norway at the time was a state without a separate language. Literature was a central precondition for the development of a living, national language.

This situation set the agenda for both writers and critics. Two lines might be followed: either making a giant step into the past, beyond Danish colonization, by bridging the gulf to the Middle Ages, to the Norwegian roots in the Viking era and the period of medieval state formation; or alternatively, building on existing literary traditions dominated by Danish writing. Both lines were followed. In order to overcome the historical gulf, historians and critics were reinvigorating the medieval saga literature. At the same time the Norwegian part of the common Dano-Norwegian culture - foremost the comedies by Ludvig Holberg - was reincorporated into a specific national line of development. Tensions between these were the source of two competing versions of a national language, New Norwegian based in the rural districts, the other based in the traditions of the academic elite.

Albeit a type of historical redefinition, this was quite different from the German case, even if the main ideas were imported from Germany. National romanticism inspired the collection of folk tales, which conquered a privileged position in the national canon, conveying a typical Norwegian mode of expression, despite their roots in a common Indo-European heritage. During the $1850 \mathrm{~s}$ and early $1860 \mathrm{~s}$ the first generation of professional writers were taking inspiration from the sagas and projecting them onto modern peasant life, implying that there was a direct continuity between present-day peasant culture and Medieval society. Moreover, the sagas were revived in historical drama à la Shakespeare and Schiller, laying the groundwork for a national drama literature.

National romantic writing came to a halt in the mid-1860s, however, due to the realization that a sovereign Norwegian state was not conceivable within the foreseeable future. The disillusionment turned the literati away from nationalist concerns and historical themes, made them move out of the country for long periods, thereby preparing the ground for what was later called "the modern breakthrough in Scandinavian literature." Inspired by the Danish critic and literary historian Georg Brandes, the Norwegian authors Bjørnstjerne Bjørnson and Henrik Ibsen became leading representatives of a radically modern literature on the European scene from the mid-1870s, shockingly critical of established powers, bourgeois ideology, gender roles and sexual mores. Thereby, they became the real founders of Norwegian national literature.

A parallel trend was the internationalization of literary production. In order to acquire inspiration, leading writers lived outside the country for long periods. Ibsen's ambiguities towards his fellow countrymen made him live outside the 
country for twenty-seven years. It is probably no exaggeration to claim that the main bulk of Norwegian literature in the second half of the 19th century was written outside the country. Rome, Paris and Munich were Norway's literary capitals up to the turn of the century, and Germany an important market outside Scandinavia. Even if Norwegian literature at this time was largely national in its orientation, it expressly transcended national borders and national ideologies at the same time. Thus, it was able to be artistically creative while simultaneously functioning within the frames of reference of national legitimacy.

Literary criticism, only sporadically in existence before the 1850 s (Beyer \& Moi, 1990), in its first systematic version, grew out of academic aesthetic traditions with a strong Hegelian bend, and with preferences for a rather anemic romanticism (Linneberg, 1992). As a counterpoint, independent and politically radical criticism developed. A split between academic criticism and the general public, as depicted by Hohendahl for Germany, was hardly found, however. Literature was among the main themes of the press, often the object of heated debate.

Norwegian literary development was reinforced by political initiative. In line with the "Norwegian system" of state support to a liberal economy, the Norwegian Parliament started to support writers by means of stipends already from the early $1860 \mathrm{~s}$, and to lay the groundwork for a national literature. Bjørnson was the first to receive such a stipend on the basis of his peasant stories (Bull, 1957). Even if economically modest, such a measure acquires a double effect. In addition to furthering literary production it places literature at the center, not only of cultural attention, but also of political interest.

The description above may give the impression of a basically harmonious nation, where all forces are drawing in the same direction. This would be a great exaggeration, however. In the latter half of the 19th century Norwegian society was full of conflict, both in the political and the cultural realm. At the same time, it can scarcely be doubted that the national situation, the exigencies of defining a distinct national identity, and finding a stable solution vis-à-vis the political union with Sweden, led to an increase of social cohesion and tolerance for heated debate.

\section{Germany - A Stratified Reading Culture}

By mid-19th century, the reading class was firmly established in Germany. To what extent, then, was there a reading culture? The ideal of personal cultivation - Bildung - has for centuries held a very strong position in Germany. But it was ambiguous due to the semi-feudal class structure, not least predominant in Prussia, 
excluding the cultivated bourgeoisie, the Bildungsbürgertum, from political power. The bourgeoisie at the same time felt the problem of demarcating themselves from the masses - who were thought unable and unworthy of full participation in cultural life. A recurring theme is the contempt for semi-cultivation-Halbbildung - supposed to reside in pretentious lower class people (Hohendahl, 1989). Behind this contempt lies both a vigorous anti-modernism, a class based contempt, and not least a growing fear of the workers' movement.

The great German school reforms in the second half of the 19th century were expressly aimed at reproducing the social stratification, by early differentiation between students and the creation of special courses preparing children for the crafts or working class occupations. In combination with strict Prussian pietism dominating the school system, the astonishing result was that the classical heritage of Goethe and Schiller was excluded from elementary school, and consequently from working class education altogether. Thus, it may be held that in the 19th century Germany had a reading culture, but that culture was drastically divided, as the lower classes were supposed to share only the less demanding parts of this culture.

The same division is found in the literary market. The number of libraries, public as well as commercial, was growing fast from the middle of the century (Martino, 1982). The same is true of publishing. About 8,300 titles were issued in 1851 . By 1875 , the number increased to almost 13,000 , and in 1910 , the number of new books was more than 30,000 (Berman, 1982). The growth in titles from the 1870 is not least due to the growth of the mass market for literature, not only popular novels but inexpensive editions of the classical literature for the broad public (Barth, 1982).

This massive proliferation of the national heritage, however, triggered vehement reactions in the Bildungsbürgertum against the commercialization of culture, even from liberal writers such as Theodor Fontane (Berman, 1988), along with criticism of modern journalism. Another quite typical example is that of Nietzsche. Not only did he regard the lower classes as unfit for literary culture, but he saw it as a threat to literary culture as such to give them access to the achievements of high culture (Hohendahl, 1989, p. 253).

These tensions were reinforced by the heavy presence of censorship. Direct censorship of publishing was abolished after 1848, but was retained in an indirect form by being displaced from publishers to bookshops. To the reading public the effect was basically the same. In theaters, direct censorship was retained throughout the century. The combination of a defensive attitude to the education of the lower classes and widespread censorship fostered an outspoken conservatism in broad strata of the reading public, as well as among producers. 
Norway - Reading Culture as Critical Mass

In Norway, the challenge was that of building up a reading culture. In order to make this happen at all, the public was bound to include broader groups of the population than the cultivated bourgeoisie. At the same time, the new literature was written with reference to popular strata such as farmers and the petty bourgeoisie; to a large degree the books were about them, and they were recruited as readers. School reforms in the 1880s and 1890s had an explicit democratic aim--a unitary national education. Textbooks for the elementary school were an important channel for spreading the emerging national literature, whereas comparable German textbooks emphasized the German popular tradition in songs and folklore (Sigurdsøn \& Hilde, 1998). It should be added, however, that the subtleties of German cultural heritage widely superseded that of the Norwegian literary and philosophical production.

A general system of public libraries was established from the late $1830 \mathrm{~s}$, parallel to the development of commercial libraries (Linneberg, 1992). A steady production of books was established in Norway not later than the 1840s (Beyer \& Moi, 1990) but on a much lower level, also measured by titles per capita, than in Germany. This discrepancy was partly a result of an underdevelopment of the literary institution.

At the same time, the constitution of the Norwegian reading public took place within a broader Scandinavian context. Up to 1890 , high quality publishing was only sporadic within Norway itself. Books from the other Scandinavian countries were widely read. With a small national market and in the absence of professional publishers, the prolific Norwegian authors were published in Copenhagen. In consequence, Norwegian authors were writing for a market in both Denmark and Norway. Moreover, they consciously sought a public outside Scandinavia, foremost in Germany, but to some extent in the rest of Europe as well. To a large extent public debate had all the Scandinavian countries as their frame of reference. Danish journals and reviews were a natural part of the Norwegian scene, at least up to the 1890 s. Initiatives to build a national publishing industry resulted in a sufficient critical mass only shortly before the turn of the century. This "decenteredness" of the reading culture and the efforts to overcome it contributed to a tempered nationalism in Norwegian literary life up to the turn of the century.

Censorship in any formal sense of the word, was non-existent, as the 1814 constitution explicitly prescribed freedom of expression (NOU, 1999, p. 27, Ch. 3). This did not prevent writers from being sentenced for what was considered open sexual descriptions offending the public morale. But the wide limits of a liberal public sphere allowed the breaking of taboos on topics such as gender roles and sexuality. 


\title{
LITERATURE IN POLITICS
}

\author{
National and Regional Literature
}

A nation-state is necessarily a coalition of regions, which for historical reasons have been united into a state. Thus, sub-national, regional specificity plays a significant role in any national literature (Griswold \& Engelstad, 1998). Regions, of course, exist prior to the state, but it is the constitution of the state which gives each area their specific meaning as a region separate from other regions, but within the common framework of this given state.

Regional characteristics are strongly present both in Norwegian and German literature, but manifest themselves in quite different ways. Both nations experienced a strong current of early realist literature with a regional touch around the middle of the century, growing out of national romanticism and inspired by the collection of folk myths and fairytales. This impetus was renewed in the neo-realist current of Heimatdichtung - a more programmatic local community or homeland literature - from about 1890 . In fact, there was a close interaction between Norway and Germany here, as the German program for homeland literature became a significant inspiration to Norwegian writers. Conversely, Norwegian homeland writers were to experience enormous successes on the German book market in the first decades of the 20th century (Foss, 1997).

Before going into this period, it is interesting to compare the two countries at an earlier point in time. As already mentioned, the hallmark of German literature up to around 1860 was its universalism. Only isolated attempts at (re)creating a national mythology are found in Lessing, Goethe or Schiller. German nationality was growing out of cultural and linguistic unity, not political. Paradoxically, one of the most influential writers over a period of hundred years was Shakespeare unser Shakespeare as he was called - hailed as a central national writer in Germany (Bate, 1997), not least because of his contrast to French classicism. Even if Schiller saw the establishment of a German theatre as an urgent national task, however, he did not appeal to German nationalism by patriotic plays hailing the German past in any way reminiscent of Shakespeare's massive dramatization of English history.

\section{Mapping the Country}

The national orientation changed with the advent of realist literature from the middle of the century. Realism required truthfulness both as concerns the experiences of the authors and their exposition of characters and scenes. Depicting people in 
their everyday reality, in their family and work setting, as well as their locale, became their overarching charge.

This pattern does not necessarily connect to a specific nationalist program but may to some extent be a product of literary competition. Writers are under pressure to bring new perspectives into the literary works, by changes in style, plot, or context. To the extent that a new region, or set of regions, has been included into the national canon, a calling emerges for descriptions of local communities not yet put on the map. On the German scene, Theodor Storm gave voice to Schleswig-Holstein, Theodor Fontane lifted up the landscapes of Brandenburg, Otto Ludwig those of Thüringen. Outside what was to become the German Reich, Adalbert Stifter described the Bohemian forests, and Gottfried Keller the Swiss countryside. Early experiments were made with the use of dialects to increase the local flavor (Bahr, 1988; Bentin et al., 1993).

In the same vein, the building of Norwegian literature had as an underlying impetus the "mapping of the country," as it was later termed by the neo-realist trend. Most Norwegian literary works between 1855 and 1890 have a very distinct geographical setting in one of the main regions in the country. ${ }^{3}$ Bjørnson started by situating his peasant stories in the North West, Alexander Kielland and Arne Garborg portrayed the South West, Amalie Skram the Bergen area, while Jonas Lie depicted the Inner East and the far North. Westerners Garborg and Skram became the first serious Oslo writers.

\section{From Realism to Neo-Realism}

The constellation of nationalism and regionalism changed, however, with the advent of the emphatic regional literature after 1890, both in Germany and Norway. In contrast to early realism, the neo-realism of late $1800 \mathrm{~s}$ had the character of a social movement. Common to both countries, the programmatic homeland literature was a reaction against the urbanized culture and literary modernism brought forth by rapid industrialization, while advocating the values of the simple rural life. The homeland movement in Germany was also a reaction to the Prussian dominance and national uniformity of the new German state. The Reich, after all, was a compound of former principalities with their individual histories and traditions. They had to be expressed as a part of the common national literature. More than that, the movement also could be seen as a protest against the big government of the Reich. Los von Berlin - "Away from Berlin" - became the device of Friedrich Lienhard, one of the leaders of the movement.

"Los von Berlin" could also be taken as a cultural motto, meaning "Look back to Weimar" while turning the back to the decadent culture of the capital 
(Foss, 1997; Rossbacher, 2000). In many ways, the movement saw itself as the heir to German Romanticism, based on collection of folk culture in the first decades of the 19th century. Despite the popular themes and its popular appeal, German homeland literature also advocated a return to the high literature of the past, to the German classics. Thus, Heimatdictung as a movement embodied a low key version of the old German universalism, with front against modernism, and thereby a leaning toward the idea of Great Germany. ${ }^{4}$

The Norwegian homeland literature movement was decisively influenced by the German Heimatdichtung (Foss, 1997; Nettum, 1975), but developed differently in several respects. Confronting industrialization and urban life, the Norwegian homeland novel retained a basically anarchistic attitude, dreaming of a time when urban life was undisturbed by external authority, not least the presence of representatives of Danish political supremacy. In contrast, while presenting a harmonizing picture of the spartan life in the countryside, along with a moderate modernization, German peasant novels could not escape romanticizing submission under strict feudal authority at the same time (Zimmermann, 1982). The anarchistic strand in the Norwegian homeland literature was reinforced linguistically. This was not least due to the introduction of New Norwegian as a literary language from the $1880 \mathrm{~s}$ on, along with extensive use of dialects, giving literary works a more local tone than the mainstream language.

\section{Homeland Literature and its Aftermath}

Despite its enormous popularity, German homeland literature remained a marginal phenomenon to the literary establishment, in its day as well as in later periods. In modern literary histories it is hardly mentioned at all (e.g. Bahr, 1988; Bentin et al., 1993), but has a modest mention in the large social histories of literature (Rossbacher, 2000; Zimmermann, 1982). In Norway, neo-realism writing has been integrated in the canonical field of literature. Even if the most explicit representatives of the neo-realist movement of the 1890 s hold a somewhat modest position in Norwegian literary history, the movement itself gave force to a broad tradition of vitalist ruralism, culminating in the work of Olav Duun and Tarjei Vesaas, who maintain an undisputed position in the Norwegian canon.

There is a paradox here. The vitalism in Norwegian literature of the first decades of the 20th century may be said to embody the motto of German neo-realism: Back to Weimar, as in a strong way it combines rural localism with classical universalism. In its highest achievements, the farm and the rural community is embodying the world, serving as the arena where humans are struggling with their fate, with God and the divine powers of life. This writing became the 
largest export success of Norwegian history after Ibsen - to Germany, where the movement had originated. Novels by Knut Hamsun, Trygve Gulbranssen, and Olav Gullvåg became the greatest bestsellers of rural literature in Germany (Foss, 1997, p. 110).

There can be no doubt that the homeland literature, with its Blut und Boden ideology, became a significant source of legitimacy of German national assertiveness, and thus indirectly of the growth of nazism in the 1920s (Zimmermann, 1982). But it should not be underestimated that some of the regional Norwegian literature gave support to fascism as well. It was of course true of the Hamsun of The Growth of the Soil - to enjoy immense popularity in Germany between the wars. Much of Norwegian homeland literature is nostalgic and some of it resolutely reactionary. Nevertheless, the great bulk kept fascist political ideas at some distance, probably because Norwegian populism was basically an anti-authoritarian ideology, whereas German nostalgia could hardly avoid the celebration of deep class cleavages, hierarchies and authoritarian rule.

\section{Literature in National Politics: The Role of the Writer}

The specificity of a national literature resides not only in linguistic and geographical qualities, but also in the formation of the role of the writer on the national scene, and the degree to which he or she can stand in the forefront of social movements, and even act as an embodiment of the national spirit. A common picture of national identity is the expression of common sentiments, that which unites all members of a society. However, conflict is just as pertinent. Even if experienced from different sides, citizens also have their conflicts in common. This is partly visible in the regional diversity of a country, which often implies a combination of complementarity and competition between regions. But it becomes unavoidably clear in a society in change, where classes struggle over power and cultural hegemony.

In the Norwegian nation-building process from the 1850 s on, it is hardly an exaggeration that the poet achieved a position as a national hero, expressing the national fate, struggling for national liberation. This national role was reinforced by a social role, that of the poet as the nation's bad conscience, always alert to social injustice and hypocrisy. From the early 1870 s Georg Brandes forcefully propagated the task of modern literature as that of relating to and setting "social problems under debate." More than any other, Bjørnson embodied both roles, as a writer and a political prophet, most aptly expressed by Ibsen in his rather ironic statement on Bjørnson: "His life was his best writing." 
Such roles necessarily become enmeshed in heated social conflicts. Throughout his life Bjørnson was constantly part of ongoing controversies over matters such as moral questions, monarchy, religion, socialism, peace policies. The $1880 \mathrm{~s}$ in particular saw vehement attacks on radical writers from the establishment, some of them sent to prison for "pornographic writing." Perhaps the core problem to be "set under debate," was that of gender roles and sexuality, raised by women and men alike; feminist writers Camilla Collett and Arnalie Skram sided with Ibsen and Arne Garborg (Engelstad et al., 1988). In the 1880s, a vital strand of feminist literary criticism grew up (Iversen. 1983). The debates over gender relations were intertwined with struggles for the female vote. In a similar vein, political struggles and literary debates constituted a fragile balance where literature found a place in the ongoing national project, by the articulation of national specificities contributing heavily to popular mobilization for national sovereignty. Despite fierce disputes, Norwegian politics converged towards dissolution of the union with Sweden and full national sovereignty in 1905.

In Germany, the situation was different. The redefinition of the spirit of the German literature entailed strong support among leading scholars and critics for the formation of the German Reich in 1871, and for its semi-democratic and authoritarian government. The German spirit embodied in the nation's literary heritage became one of the most salient sources of legitimacy for the consolidated Germany. However, the ensuing internal tensions could not be channeled into a process of national liberation, even if many slogans declared the formation of the Reich as a liberation process. Liberal forces were suppressed by successive wars, by the formation of the Reich, and by a pseudo-democratic political structure. Neither were they channeled into the establishment of a well functioning public sphere, where social tensions could be exposed and discussed, if not resolved. Rather, what took place was a fairly strong and arbitrary repression of political debate, both as regards formal censorship and informal constraints on public discussion (Berman, 1982; Sagarra, 1971).

Such a cultural climate is hardly conducive to artistic articulation of political values, and goals common to the German nation became difficult. Few German writers were able to respond creatively to their situation. No female authors of any import came forth, the writer closest to feminist problems being Fontane in Effi Briest. Nationalist writers supported the establishment, but more importantly the classical German literary heritage was taken in as justification of national expansionism.

Nietzsche's vitriolic criticism of German culture throughout the 1880 s, however largely unnoticed during his life as an active writer, should be seen against this background. Paradoxically, as a result of the German cultural impasse, the radical Scandinavian literature of August Strindberg, J. P. Jacobsen, Bjørnson and Ibsen 
assumed the place as the leading modern endeavor in Germany of the $1880 \mathrm{~s}$ and 1890s. Ironically, it fell on the Dane Georg Brandes to serve as a door opener for Nietzsche on the European continent (McCarthy, 2000).

\section{The Power of the Writer}

If writers are to exercise cultural leadership, they must be in command of power resources. Being visible to the public is not enough, even if it is a precondition. To have a social impact, to be heard as having something important to say, the writer must be recognized as a representative of the literary institution, to profit from aesthetic authority. In addition, the influential writer stands forth as a representative of a moral position.

The interventionist writer, the writer with a cause, is the most common type. Emile Zola, was the prototypical case of an auteur engagé with his intrusion into the Dreyfus affair. In this case, he was undoubtedly exerting power to a significant degree. He had the exceptional opportunity to intervene at a point where his voice could offer decisive support to one of the parties in a conflict that would threaten French national unity, the struggle between the traditionalist and the republican conception of the nation. For most engaged writers such a position is what they dream of, but never achieve. The normal situation of the interventionist writer is that of the partisan, the individual who gives voice to a party or a movement, but without transcending that movement. Ame Garborg, the leading representative of the movement for the New Norwegian language is perhaps the best example from Norway. A typical auteur engagé in the German realm was Gerhard Hauptmann, in late 19th century the spokesman of the working class.

An alternative position is that of the writer influencing the world-view of the public, their sense of self or their core values. Charles Dickens, with his attacks on narrow utilitarianism and his emphasis on the value of creativity, is a good example. Emile Zola, again, as the advocate of naturalism is another. In Norwegian literature, Henrik Ibsen's searching criticism of bourgeois society and his accompanying self-criticism has a similar character. In the German literature of the latter half of the 19th century, Theodor Fontane is probably the character coming closest to such a position, even if he hardly can be said to command a similar critical potential as a Dickens or Ibsen.

A small group of writers ascends to the position of rallying symbol, which speaks on behalf of the nation as a whole and articulates its roots. This position does not exclude the writer from taking contested standpoints in public debate. One may even ask if it is possible to attain such a position without being also the 
subject of attack. The main point is that the writer touches and exposes the deepest concerns in the nation, which are never free of conflict. In France of the 19th century, the exiled Victor Hugo may be said to hold such a position. In Norway, Bjørnstjerne Bjørnson, like Hugo a very controversial person, came close to being the spokesman of the nation as a whole. In Germany, however, during the first hundred years after Goethe's death, it is hard to obtain a glimpse of such personalities. Maybe the one of the Mann brothers could aspire to the role. But Thomas Mann was too subtle in his writing and too distant from political realities to command the attention of the nation, whereas Heinrich Mann remained too marginal on the national scene.

This brief sketch suggests that the power of the writer, in addition to his or her literary qualities, is connected to his or her ability to act in concert with greater forces, parties, and movements. From the central position of a Hugo or Bjørnson, the writers are able to transform people's choices and standpoints into common social and moral concerns of national significance, by focusing the public attention, giving voice to, and confirmation of, sentiments dimly present. They make themselves heard in virtue of their words, but also on the basis of the social role anchored in the literary institution.

The power of the writer as a stubborn oppositional, foremost embodied by Ibsen, is another matter. They gain influence by being able to pick up deep antinomies in dominant thinking. The effects may be diffuse and difficult to uncover, but maybe in the long run they are the most enduring.

\section{CONCLUSIONS}

Nations develop as imagined communities (Anderson, 1983), communities that require a common language and means of communication, but also a common imagination - collective identities and modes of self-reflection - in order to be sustainable. Identities are maintained and shaped by the interpretation of experience, individual and collective, real or imagined. A common history is one such mode of imagination, a common language and literature is another. Compared to history, literature has the advantage that it actualizes not only the cultural achievements of the past, but also the present status of the community, and points forward to its future challenges.

What has been told is a tale of two nations, separately and in interaction over a century. Germany was the larger part, and culturally more advanced, but Norway was able to play a visible role in the relationship for a certain period. A central factor in the nation-building in the 19th century was the common problematique of the nation, the sense of its mission. German nation-building 
was fostered by military expansion, Norwegian by achieving national sovereignty by breaking out of an undesired political union. In Germany, the existing literary history was reinterpreted to match the exigencies of the kleindeutsch national solution. In Norway, the task was that of building a national literature virtually from scratch.

Differences in class structures and social institutions - book markets, censorship, schools, universities - significantly affected the position of literature in social life. By the middle of the 19 th century, Germany had a vast reading public, and an advanced academic and cultural elite. But it became increasingly nationalist, under the pressure of authoritarian and expansive politics on the one hand, and caught in a defensive position in class conflict on the other. The cultural deficiencies in Norway, on the other hand, led to a more energetic mobilization of popular strata into cultural development, and paradoxically, to a broader international orientation.

The basic universal spirit of German literature, connected to the unsurpassable achievements of the period 1760-1830, came into conflict with the formation of the national state under Prussian leadership. The result was cultural conservatism and artistic stagnation. Political exigencies in Norway at the same time did not exclude the expression of social conflict, but fostered a resolutely modern, critical literature, in its orientation national and international at the same time.

The roles were soon to be reversed, however. From the turn of the century, Norwegian literature entered into a long phase dominated by neo-realism and vitalism that in many ways served the consolidation of the nation after sovereignty was achieved in 1905. The long-term cost of the new national orientation was a gradual withdrawal from the international literary scene - with the exception of German readers hungering for Heimatdictung from the North. After the turn of the century Norway had a sustainable literary life of her own, a critical mass of publishing, and a sufficiently large reading culture. But the ensuing distance to the European literary avant-garde was never abridged.

In Germany, growing social tensions could no longer be withheld. Partly as a result, the first decades of the 20th century were to be one of the most fertile epochs in the history of German literature. While at the same time, a harmonizing homeland literature upheld its grip on the readership, giving support to authoritarian nationalism.

\section{Characteristics of a National Literature}

The foregoing observations also invite reflections on some characteristic traits of national literatures. First, by virtue of being national, the unity of a national 
literature is often exaggerated. A national literature is a compound of regional literatures. However, this does not presuppose a specific regionalist movement, even if that did occur in most European countries in the late 19th century. The impulse towards "mapping the country" was one of the basic processes in the constitution a national literature of the 19th century. From national romanticism, it became one of the main features of realist writing, both in Germany and Norway. In Bjørnson's words, envisioning the country "fra grensen og ut til de drivende garn" - from the frontier and out to the floating fishing nets. Interestingly, however, this is often denied in the literary establishment, presumably because the regional is conceived as parochial, whereas the "high" national literature is expected to be universal. ${ }^{5}$ But if nations are more universal than are the regions of which they are comprised, they are so in virtue of the constellation of these same regions.

Second, the coexistence of genres in the national tradition has as a further consequence that the dividing line between high and low are drawn differently in different nations, something that also influences the development of canonical writing. When realist writing developed in Germany around the middle of the 19th century, it happened on the backdrop of "Weimar," the great achievements of the enlightenment and early romantic literature. Realism could never compete with the quality of these works, and was relegated to the second order. When imported to Norway, however, realist writing contributed to establishing the basis for a new national literature, and thereby it achieved canonical status at an early stage. In the next round, the German homeland movement inspired neo-realist writing in Norway, which became one of the impulses in the development of a strong vitalist strand, later to be re-exported as high quality contributions to a literature regarded as inferior in Germany, despite (or maybe because of) its being widely read.

Third, the character of a national literature is to a large extent influenced by the elaboration of the roles of writers, both in a social and political context. Writers are judged not only by their writing, but also related to their actions as spokesmen on social questions. Writers' alliances with successful social movements have an impact on the formation of the canon. To be sure, literary quality is a precondition for recognition, but canon formation is always a question of selection. The social visibility of the writer enhances the possibility of being included in the canon. Fourth, a national literature not only embraces that which unites a nation such as values or sacred memories: it also embodies the serious conflicts and combats that threatened its unity - competing religious beliefs, class struggles, urban-rural divides. Even if they are now part of the common experience, these conflicts also demonstrate possible challenges to national unity in the future. 


\section{Institutions and Legitimacy}

In addition to the effects of the writer as spokesman, a separate set of political and social effects of literature as an institution should be pointed out. The position of literature in the national power structure is not limited to political events but concerns national identity in the relationship between social institutions, foremost the public sphere and state power.

Both in Germany and Norway literature became a major source of the legitimacy of the nation-state, and consequently of state power. The effects on legitimacy imply an enhancement of state power in two directions. First, internally, literature indirectly contributes to popular support for modern social institutions, which to a large extent are built up by the state. A significant, albeit not the only, aspect of these institutions - school, welfare state, family structure - is their disciplinary effects. Hence, these have been under attack for a long time, not least by partisan novels. Then, how can literature be said to support them?

One possible answer is that much literature, after all, is conservative, and has come to defend established structures rather than criticize them. That may be so. More significant, however, is a reflection that springs out of a meta position: the uses of literature do not take place in a social vacuum. Literature in any version, and the avant-garde most of all, presupposes long term socialization - learning, disciplining - to achieve reading competencies. Even anti-authoritarian writing requires discipline in order to be understood. Moreover, as a well developed social institution, literature finds its place among other institutions, be they schools, markets, or universities. Those who operate within the position of the literary institution mostly cannot escape recognizing the existence of other social institutions as well.

On the other side of the coin, literature is posited at the center of the social realm for free discussion. The substance of serious literature is the moral problems and normative antinomies present in any society, which it explores and exposes for social discussion. Even in autocratic regimes literature highlights social and moral dilemmas. In the formulation of Thomas Mann, the fate of the writer is to be society's fool, i.e. the one who continuously steps on the sore toes of the social establishment, even if he is powerless when it comes to changing them. In autocratic regimes literature maintains a breathing hole, in democratic nations it comes to the defense of free speech, which always may come under attack.

Second, by giving legitimacy to the nation, literature becomes a source of support in its external relations with the rest of the world. Among Germans an intense feeling prevailed that their country had a special, civilizing mission (Greenfeld, 1992). German expansionism in the latter half of the 19th century 
is hardly conceivable without the collective self-image of das Land der Dichter und Denker. Tragically, it turned into das Land der Ricther und Henker, partly based on the same sources of legitimacy. This can hardly be seen as a direct effect of literature, but indirectly literature was used to build up an inflated national self-image without potential of resistance against being used for expansionist purposes.

By comparison, Norway was in a fortunate position. It fostered more outspoken writers, hosted more open public debate, and had few if any foreign policy ambitions. This should not be interpreted as a sign of moral superiority. Norway's main political and cultural program was that of liberation from bonds unyearned for, not that of creating relationships to other states. The country did not have resources to conceive any kind of mission vis-à-vis other countries, except setting foot on the North and South poles. In contrast to Germany, its writers showed themselves relatively powerful at home. For a century this remained so. In the long run it contributed to the creation of a nation that is peaceful, but generally somewhat at a distance from the rest of the world.

These cases make it clear that even if literature can be used to further political goals, it cannot be reduced to an instrument for these goals. Due to its diversity, literature transcends politics and national identities. As a general rule, this is true of the aggregate achievements by individual writers. In actual practice, however, the diversity of literature is not only the product of individual writers, but just as much of the norms and ideologies of critics and academics, those who construct and interpret the national canon. These are probably the most important groups in determining the position of literature as expansionist, inward-looking, or standing in a critical dialogue across national borders.

\section{Brief Postscript: A Wider Perspective}

The observations made here are most relevant to the second wave of nation-building in Europe. In other periods, countries certainly establish their national literature in other ways. Alternatively, nation-building may simply not take place, or crumble and wither away.

In Bearing Witness, a thorough investigation of the Nigerian novel, Wendy Griswold (2000) depicts the rise and possible fall of a national literary institution. Up to the 1990s, intellectuals expected to be able to build a specific Nigerian literature. But would it reach a larger reading public? The competition from mass media, in combinations with low political stability and an educational system in great difficulties, are signs that the endeavor will be more than difficult. In Griswold's words: "The reading class remains, but it is isolated. 'We do not yet 
have a reading culture,' discouraged writers and booksellers admit, but someday we will. ... They may be kidding themselves" (Griswold, 2001).

Less drastic conclusions follow from the work of Sarah Corse on the United States and Canada. Due to the close connection to the British heritage, a genuine national literature was not established in the U.S. before the advent of 20th century. At the same time, a major impetus for the establishment of an American national literature was the need of the U.S. to distinguish itself from Britain (Corse, 1997). Likewise, only fifty years later, a Canadian national literature was built out of desires to distinguish Canada from other nations (Atwood, 1972), most of all from the U.S. Canada, like Norway culturally a latecomer, needed to position itself vis-à-vis its big neighbor. And, like Norway, state patronage of literature was one of the means by which this goal was to be achieved.

Corse does not take up the regional dimension, however, when she discusses canonical works. ${ }^{6}$ In her account, national features are linked to conceptions of individuals and groups, foremost family constellations and their relationship to the outer world. This world is generalized as "nature" or "society," but has no further political characteristics. Maybe regionality must be interpreted differently in American and Canadian writing than in European, due to different processes of nation-building. Or maybe it is rather a question of lifting extant studies on regionality in Northern American literature up to the realm of national literature.

Anyway, the quest for a national literature is posed differently after the emergence of the culture industry. What a nation needs is recognition of its capacity for cultural creativity, and not necessarily a national literature. In the latter half of the 19th century the book as medium of artistic creation had the widest distribution. In other contexts, alternative media may emerge, taking the place of literature. At the end of the 18th century Schiller called for a German theater to express the spirit of the nation. To a large extent the U.S. may be seen as a similar case. From the beginning of the 20th century other media such as film, and later television, also embodied the specific American culture. Hence, maybe a national literature does not have the same meaning in the U.S. as it had and still has in Europe. When it comes to cultural expansionism at least, American TV series are more powerful than American books in propagating the American way of life, at home and abroad. If Canada wants to distinguish itself from the U.S., an alternative strategy would have been to engage in massive funding of a national movie and TV industry. But this is hardly an open road. A small country has neither the means nor the home market to compete with Hollywood. Support for literature is far less expensive, and entails even smaller risks. And in modern societies it is the first option of the reading class. 
The conclusion seems to be near at hand: support for literature in small countries, Canada as well as Norway. Presently, the larger European countries also see the need for state protection of their national literature, by state patronage or legal regulation. Literature, nation and state are still intertwined.

\section{NOTES}

1. In Germany, the first chair in Germanistik was filled in 1810 , but the first professor of Germanistik to publish a literary history was Wilhelm Scherer (Über den Ursprung.der deutschen Literatur, 1864); while his influential Geschichte der deutschen Literatur was issued in the early $1880 \mathrm{~s}$. The first professor of Norwegian literature was Cathrinus Bang, research fellow from 1858 and professor from 1867. Bang lectured on literary history, but never published anything. Thus, he left the field of literary history open to non/academic authors.

2. Already by 1830 were 16 versions issued, and the number was steadily growing. Among the more specialized should be mentioned: Was muss der Unteroffizier von der deutschen Literatur wissen? Bilder aus der Geschichte der deutschen Nationalliteratur (Batts, 1993).

3. Dahl (1984, p. 239) gives a somewhat different interpretation.

4. "Los von Berlin" was also a reply to the slogan "Los von Rom," launched by an Austrian movement working for unification with Germany on the basis of conversion from Catholicism to Protestantism.

5. Alternatively, universality is sought directly in the local, as is quite common in Norwegian literary criticism (Engelstad, 1996).

6. Even if Quebec separatism is amply described by Corse, only one of the books analyzed is Quebecois. Possible regional literary specificities are absent.

\section{ACKNOWLEDGMENTS}

First presented to the Research Stream on Arts and Power, at the 5th Meeting of the European Sociological Association, Helsinki, August 28-31, 2001. Thanks to Grete Brochmann, Irene Engelstad, Wendy Griswold, for comments on an earlier version. All misunderstandings are the responsibility of the author.

\section{REFERENCES}

Anderson, B. (1983/1991). Imagined communities. London: Verso.

Atwood, M. (1972). Survival. Toronto: Anansi. 
Bahr, E. (Ed.) (1988). Vom Realismus bis sur Gegenwartsliteratur. Geschichte der deutschen Literatur, $B d$ 3. Tübingen: Francke Verlag.

Barth, D. (1982). Zeitschriften, Buchmarkt und Verlagswesen. In: H. A. Glaser (Ed.), Von Nachmärz zur Gründerzeit. Volume 7 of H. A. Glaser (Ed.), Deutsche Literatur. Eine Sozialgeschichte. Hamburg: Rowohlt.

Bate, J. (1997). The Genius of Shake speare. London: Picador.

Batts, M. S. (1993). A history of histories of German literature 1835-1914. Montreal: McGill-Queen's University Press.

Bentin, W., Ehlert, K., Emmerich, W., Hoffacher, H., Lutz, B., Meid, V., Schnell, R., Stein, P., \& Stephan, I. (1993). A history of German literature from the beginning to the present day. London: Routledge.

Berman, R. A. (1982). Litermische offentlichkeit. In: F. Trommier (Ed.), Jahrhundertwende: Vom Naturalismus zum Expressionismus. Volume 8 of H. A. Glaser (Ed.), Deutsche Literatur. Eine Sozialgeschichte. Hamburg: Rowohlt.

Berman, R. A. (1988). Literary criticism from empire to dictatorship, 1870-1933. In: P. U. Hohendahl (Ed.), A History of German Literary Criticism, 1730-1980. Lincoln: University of Nebraska Press.

Beyer, E., \& Moi, M. (1990). Norsk litteraturkritikks historie, 1770-1940. Vol. 1: 1770-1848. Oslo: Universitetsforlaget.

Blanning, T. C. W. (2002). The culture of power and the power of culture. Old regimes in Europe 1660-1789. Oxford: Oxford University Press.

Bourdieu, P. (1993). The field of cultural production. Cambridge: Polity Press.

Bull, F. (1957). Fra Februar-revolusjonen til Forste verdenskrig. In: F. Bull, F. Paasche. A. H. Winsnes \& P. Houm (Eds), Norsk Litteraturhistorie (Vol. IV.2). Oslo: Aschehoug.

Corse, S. (1997). Nationalism and literature. Cambridge: Cambridge University Press.

Dahl, W. (1984). Norges litteratur IL Tid og tekst 1884-1935. Oslo: Aschehoug.

Engelstad, F. (1996). Literary regionalism: Regional effects of state support for literature in Norway. In: W. Griswold \& F. Engelstad (Eds), Places Within, Places Beyond. ISF-Report 96:12. Oslo: Institute for Social Research.

Engelstad, F. (2001). Expressive forms as generators, transmitters and transformers of social power. International Encyclopedia of the Social and Behavioral Sciences, Vol. 8. Oxford: Elsevier.

Engelstad, I., Hareide, J., Iversen, I., Steinfeld, T., \& Øverland, J. (Eds) (1988). Norsk Kvinnelitteraturhistorie (Vol. 1, pp. 1600-1900). Oslo: Pax.

Foss, G. (1997). Heimstad, dikting, identitet. In: D. Slettan \& O. S. Stugu (Eds), Det nasjonale $i$ det lokale, det lokale i det nasjonale. KULT Skrifiserie No. 92. Oslo: Norges Forskningsråd.

Greenfeld. L. (1992). Nationalism. Five roads to modernity. Cambridge: Harvard University Press.

Griswold, W. (1987). A methodological framework for the sociology of culture. Sociological Methodology, 17, 1-35.

Griswold, W. (2000). Bearing witness. Princeton: Princeton University Press.

Griswold, W. (2001). The ideas of the reading class. Contemporary Socislogy, 30, 4-6.

Griswold, W., \& Engelstad. F. (1998). Does the center imagine the periphery? State support and literary regionalism in Norway and the United States. Comparative Social Research, I7. $129-175$.

Habermas, J. (1989). The structural transformation of the public sphere: An inquiry into a category of Bourgeois society. Cambridge: Polity Press.

Hechter, M. (2000). Containing nationalism. Oxford: Oxford University Press. 
Hobsbawm, E. (1962). The age of revolution. London: Weidenfeld and Nicholson.

Hobsbawm, E., \& Ranger, T. (Eds) (1983). The invention of tradition. Cambridge: Cambridge University Press.

Hohendahl, P. U. (1982). Literaturkritik und literaturgeschichte. In: H. A. Glaser (Ed.), Von Nachmärz zur Gründerreit. Volume 7 of R. A. Glaser (Ed.), Deutsche Literatur. Eine Sozialgeschichte. Hamburg: Rowohlt.

Hohendahl, P. U. (1989). Building a national literature. Germany 1830-1870. Ithaca: Cornell University Press.

Hüppauf, B. (1972). Einleitung: Über die Anfänge der deutschen literaturgeschichtsschreibung. In: B. Hüppauf (Ed.), Literaturgeschichte Zwischen Revolution und Reaktion. Frankfurt a. M.: Athenäum Verlag.

lngram, W. (1992). The business of playing. Ithaca: Cornell University Press.

Iversen, I. (1983). Kvinnelige kritikere og etableringen av en kvinneoffentlighet i 1880-åra. Norskrift, 38.

Kittang, A., Meldahi, P., \& Skei, H. H. (1983). Om litteraturhistorieskriving. Perspektiv på litteraturhistoriografiens vilkär og utvikling i europeisk og norsk sammenheng. Bergen: Alvheim og Eide.

Lamont, M., \& Fournier, M. (Eds) (1992). Symbolic boundaries and the making of inequality. Chicago: University of Chicago Press.

Linneberg, A. (1992). Norsk litteraturkritikks historie, 1770-1940. Vol. 2: 1848-1870. Oslo: Universitetsforlaget.

Mann, M. (1986). The sources of social power. Volume 1. A history of power from the beginning to A.D. 1760. Cambridge: Cambridge University Press.

Martino, A. (1982). Publikumsschicten und leihbibliotheken. In: H. A. Glaser (Ed.), Von Nachmär zur Gründerzeit. Volume 7 of H. A. Glaser (Ed.), Deutsche Literatur. Eine Sozialgeschichte. Hamburg: Rowohlt.

McCarthy, J. A. (2000). Die Nietzsche-Rezeption in der Literatur 1890-1918. In: Y-G. Mix (Ed.), Naturalismus, Fin de Sièecle, Expressionismus, 1890-1918. Volume 7 of R. Grimminger (Ed.), Hansers Sozialgeschichte der Deutschen Literatur vom 16. Jahrhundert bis zur Gegenwart. Munich: Carl Hanser Verlag.

Melucci, A. (1989). Nomads of the present: Social movements and individual needs in contemporary society. London: Century Hutchinson.

Nettum, R. N. (1975). Generasjonen fra 1890-årene. In: E. Beyer (Ed.), Fra Hamsun til Falkberget. Volume 4 of E. Beyer (Ed.), Norges Litteraturhistorie. Oslo: Cappelen.

Rokkan, S. (1970). Citizens, Elections, Parties. Oslo: Universitetsforlaget.

Rossbacher, K. (2000). Heimatkunst der frühe Modeme. In: Y.-G. Mix (Ed.), Naturalismus, Fin de Siècle, Expressionismus, 1890-1918 \& Volume 7 in R. Grimmijnger (Ed.), Hansers Sozialgeschichte der deutschen Literatur vom 16. Jahrhundert bis zur Gegenwart. Munich: Carl Hanser Verlag.

Sagarra, E. (1971). Tradition and revolution. German literature and society 1830-1890. New York: Basic Books.

Seip, J. A. (1957). Det 'norske system'.

Sigurds $ø$ n, R., \& Hilde, K. (1998). Det nasjonale i norske, tyske og franske skolebøker 1860-1905. To sammenlignende studier. KULT Skriftserie nr. 100. Oslo: Norges forskningsråd.

Slagstad, R. 1998. De nasjonale strateger. Oslo: Pax.

Smith, A. D. (1991), National identity. London: Penguin.

Smith, A. D. (1999). Myths and memories of the nation. Oxford: Oxford University Press. 
Thiesse, A.-M. (1999). La création des identités nationales. Paris: Editions du Seuil.

Weber, M. (1922). Wirtschafi und gesellschaft. Tübingen: J. B. C. Mohr.

Zimmermann, P. (1982). Heimatkunst. In: F. Trommler (Ed.), Jahrhundertwende: Vom Naturalismus zum Expressionismus. Volume 8 of H.A. Glaser (Ed.), Deutsche Literatur. Eine Sozialgeschichte. Hamburg: Rowohlt. 